\title{
FEEDING ECOLOGY OF NON-NATIVE CENTRARCHIDS (ACTINOPTERYGII: PERCIFORMES: CENTRARCHIDAE) IN TWO IBERIAN RESERVOIRS WITH CONTRASTING FOOD RESOURCES
}

\author{
Francisco N. GODINHO ${ }^{1^{*}}$ and Maria T. FERREIRA ${ }^{2}$ \\ ${ }^{1}$ Conselho Nacional da Água, Lisbon, Portugal \\ ${ }^{2}$ Centro de Estudos Florestais, Instituto Superior de Agronomia, University of Lisbon, Portugal
}

Godinho F.N., Ferreira M.T. 2014. Feeding ecology of non-native centrarchids (Actinopterygii: Perciformes: Centrarchidae) in two Iberian reservoirs with contrasting food resources. Acta Ichthyol. Piscat. 44 (1): 23-35.

Background. Two North American fish species have been particularly successful in Iberian reservoirs, the largemouth black bass, Micropterus salmoides (Lacepède, 1802) and the pumpkinseed, Lepomis gibbosus (Linnaeus, 1758), but information on their ecology is still scarce, limiting their effective management and control. To increase the knowledge about the ecological mechanisms underlying bass and pumpkinseed invasion of freshwater systems, their feeding ecology and population descriptors are contrasted in two Iberian reservoirs differing in available resources.

Materials and methods. The studied reservoirs, situated in tributary streams of the Guadiana River, were sampled during the same months for a total of eight times, spanning two years. Fish samples were made by using electrofishing from a boat in the littoral area and trammel nets. Zooplankton and littoral benthic invertebrates were sampled concurrently with fish sampling. Fish diet was studied by examining individual stomach contents. The dominance of the different items in the diet of each species size-class was determined using the modified Costello diagram, diet overlap was estimated with Pianka's index and prey selection was assessed with the Manly-Chesson's alpha. Back-calculated length-at-age and body condition were also assessed for each fish.

Results. Invertebrates were dominant in the diet of pumpkinseed whereas invertebrates and pumpkinseed dominated the diet of bass. Both species demonstrated an overall dietary opportunism and a considerable food spectrum, with pumpkinseed eating fish and macrophytes. Feeding selectivity was observed that varied with species, size-class, reservoir and sampling period. Fish became the main prey for larger bass and the shift to piscivory was related to pumpkinseed availability. The dietary changes associated with pumpkinseed growth in native environments were not observed in the reservoirs. Dietary overlaps varied with sampling period, being frequently high. Differences in abundance, growth and body condition of bass and pumpkinseed were evident between reservoirs. Conclusion. The ability to use several food items and to feed opportunistically likely facilitated the widespread success of the centrarchids in variable Iberian reservoirs. Moreover, our results seem to support the occurrence of resource competition between pumpkinseed size classes and between smaller bass and pumpkinseed.

Keywords: invasive, Micropterus salmoides, Lepomis gibbosus, ecology, diet, reservoirs, Iberia, biotic interactions

\section{INTRODUCTION}

Water availability is highly irregular in southern Iberia and, as a consequence, numerous dams have been built to store water from wet to dry periods, making riverine reservoirs (henceforth referred to simply as reservoirs) a conspicuous freshwater environment (Clavero et al. 2013). In a region almost devoid of natural lakes, reservoirs have offered new areas for native fluvial fish to colonise and promoted the naive introduction of several exotic fish, becoming some of the most heavily invaded systems in the world
(Hermoso et al. 2011). Two North American centrarchids have been particularly successful among the species introduced, the largemouth black bass, Micropterus salmoides (Lacepède, 1802), a primary piscivore, and the pumpkinseed sunfish, Lepomis gibbosus (Linnaeus, 1758), a specialised molluscivorous (Keast 1978). The sunfish was first introduced in the Spanish lake Banyoles around 1910 (García-Berthou and Moreno-Amich 2000b) but has spread westwards only in the 1970s. The bass was introduced to Portugal in 1952 and later to Spain (1955), and both cen-

\footnotetext{
* Correspondence: Dr. Francisco Godinho, Conselho Nacional da Água, Rua de O Século, 51, 2. 1200-433 Lisboa, Portugal, phone: +351213231550; fax: +351213231523; e-mail: (FNG) francisco.godinho@sg.maot.gov.pt and franciscogodinho111@gmail.com; (MTF) terferreira@isa.ulisboa.pt.
} 
trarchids presently co-occur in the majority of Iberian bodies of water, particularly in reservoirs. These same species were also introduced in many other world regions, becoming among the taxa most frequently established outside their natural ranges.

Scientists have long recognised the importance of feeding strategies in the ecological success of animal species, but, despite the importance of invasive bass and pumpkinseed as negative drivers of native fish assemblages (Clavero et al. 2013) and, in the case of bass, as a favoured angling species (Oliveira et al. 2009), available information about their feeding ecology in Iberia is still limited. Investigations conducted so far have addressed a single system (García-Berthou 2002), only one species (Zapata and Granado-Lorencio 1993) or a sole sampling period (Godinho et al. 1997), thus precluding a more comprehensive understanding of these species ecology in variable Iberian freshwater ecosystems.

In North America, the largemouth bass and Lepomis spp., particularly the bluegill, Lepomis macrochirus Rafinesque, 1819 (a sister species of the pumpkinseed sunfish not present in the Iberian Peninsula), are frequently sympatric in ponds and natural lakes (Shoup et al. 2007), and inter-specific interactions are often strong and dependent on size, since bass can use Lepomis spp. as prey but both taxa may share the same feeding resources at smaller sizes (Olson et al. 1995). Moreover, competitive interactions in juvenile Lepomis spp. are reportedly common in these taxa native habitats (Arendt and Wilson 1999).

To increase the knowledge about the ecological mechanisms underlying bass and pumpkinseed invasion of Iberian freshwater systems, in the presently reported study we contrast the feeding ecology and population descriptors of bass and pumpkinseed in two southern Iberian reservoirs with distinct available food resources. We were particularly interested in examining the ability of these introduced species to use the available resources, as well as to gain evidence on the occurrence of sizedependent biotic interactions in the bass-pumpkinseed association such as those reported for the bass-bluegill association in North America.

\section{MATERIALS AND METHODS}

Study sites and field sampling. Two warm-water reservoirs located in tributaries of the Guadiana River (southwest Iberia) were studied: the Monte Novo Reservoir (MN) and the Tapada Grande Reservoir (TG) (Table 1). Both reservoirs are distinct in some environmental conditions, noticeably in the resources available.

The reservoirs were sampled during the same months in consecutive weeks for a total of eight times, spanning two years (April, June, August, and November in 1992 and March, April, May, and November in 1993). Fish samples were made by using electrofishing from a boat in the littoral area $(200 \mathrm{~V}, 3-6 \mathrm{~A}, \mathrm{DC})$ and nylon multi-mesh trammel nets (outer panel mesh: $25 \mathrm{~cm}$; inner panel meshes: 25 and $50 \mathrm{~mm}$ ) that were set overnight in non-littoral areas (i.e., limnetic and bottom).
After collection, bass and pumpkinseed were measured for total length (TL) to the nearest $\mathrm{mm}$ and weighed for total weight (TW) to the nearest $0.1 \mathrm{~g}$. Scales were removed bellow the lateral line near the tip of the pectoral fin. Pumpkinseed and bass subsamples spanning available sizes were placed on ice after capture and deep-frozen within $4 \mathrm{~h}$, being later taken to the laboratory.

Laboratory methods. In the laboratory, each fish was eviscerated, weighed (eviscerated weight, EW) and had its stomach content examined by using a binocular dissecting microscope, with food items identified to the lowest practical taxon and counted. In total, 355 pumpkinseed and 166 bass stomachs in TG reservoir, and 865 pumpkinseed and 146 bass stomachs in MN reservoir were examined for this study, with observations focusing on stomachs in which the prey could be clearly identified. Three size classes were established for each species to examine size-related diet shifts: small $(<50 \mathrm{~mm}$ TL), intermediate $(50-100 \mathrm{~mm})$, and large $(>100 \mathrm{~mm})$ for pumpkinseed and: small $(<100 \mathrm{~mm} \mathrm{TL})$, intermediate $(100-200 \mathrm{~mm})$, and large $(>200 \mathrm{~mm})$ for bass.

The age of each fish was determined by counting annuli from scale projections and the TL at age was backcalculated by using the Fraser-Lee method (Bagenal and Tesch 1978).

Data analysis. To evaluate the dietary importance of each food category, the frequency of occurrence (FO) and percent prey number $(\% N)$ were used. Percent number is the number of individuals of a prey category divided by the total number of individuals and expressed as a percentage, after pooling the stomach contents of all fish, whereas FO is the percentage of stomachs where a food category was present.

To describe the general prey importance and feeding strategy of each species size-class we used the modified Costello diagram (Costello 1990). The Costello diagram is based on a two-dimensional representation, where each point relates the occurrence of a prey item to its abundance (all in percent). Amundsen et al. (1996) modified the Costello diagram by replacing the abundance of a prey item by its prey-specific abundance, which equals:

$$
P_{i}=100\left(\sum S_{i}\right) \cdot\left(\sum S_{t i}\right)^{-1}
$$

where: $P_{i}$ is the prey-specific abundance of prey $i ; S_{i}$ is the stomach content (number) comprised of prey $i$; and $S_{t i}$ is the total stomach content in only those predators with prey $i$ in their stomach. The dominant prey are closer to the top right corner, whereas the other diagonal corresponds to feeding strategy; prey with low occurrence but dominant by number correspond to individual specialisation and are closer to the top left corner.

Correspondence analysis (CA) was used to assess the main sources of diet variation in pumpkinseed and bass. $\mathrm{CA}$ is an ordination technique that reduces a species $\times$ samples matrix to a few dimensions explaining most of the variation and has been applied to dietary data (Marshall and Elliott 1997). The analysis was performed on matrices of diet categories $\times$ sample (each individual fish), with diet assessed as the numerical proportion of each food category. To increase the homogeneity in the 
analysis, rare dietary items were grouped into an "other" dietary category and proportions were arcsine (squareroot) transformed. Multivariate analysis of variance (MANOVA) of the sample (stomach) scores in the first two CA dimensions were used to interpret the pumpkinseed and bass dietary gradients according to fish length (size-class) and reservoir.

Temporal variation in the number of major prey categories eaten by size classes of largemouth bass and pumpkinseed was assessed with analysis of variance (ANOVA).

To evaluate prey selection (for macroinvertebrates and zooplankton), the Manly-Chesson's alpha (Chesson 1978, 1983) was determined in each sampling occasion with availability data and for each species size-class. The index formula is:

$$
\alpha=\left(r_{i} \times p_{i}^{-1}\right) \times\left[\sum\left(r_{j} \times p_{j}^{-1}\right)\right]^{-1}
$$

where: $r_{i}=$ the proportion of food item $i$ in the $\operatorname{diet}(i=1,2$, $\ldots, m), p_{i}=$ the proportion of food item $i$ in the environment and $m=$ the number of food items in the environment (Chesson 1983). A value of $a=\left(1 \times m^{-1}\right)$ occurs when a prey is consumed in proportion to its abundance, whereas values above $\left(1 \times \mathrm{m}^{-1}\right)$ indicate preference and values below $\left(1 \times \mathrm{m}^{-1}\right)$ indicate avoidance. The index was only calculated in sampling occasions with at least 5 bass or pumpkinseed with stomachs presenting well preserved food in a respective size-class and was separately determined for zooplankton and for benthic macroinvertebrates. To reduce some of the biases associated with selection indices (Chesson 1983) only prey with $\mathrm{FO}>5$ in

Characteristics of Monte Novo and Tapada Grande reservoirs, Iberian Peninsula

\begin{tabular}{|c|c|c|}
\hline & $\begin{array}{c}\text { Tapada Grande } \\
37^{\circ} 40^{\prime} \mathrm{N}, 7^{\circ} 30^{\prime} \mathrm{W} \\
\end{array}$ & $\begin{array}{c}\text { Monte Novo } \\
38^{\circ} 30^{\prime} \mathrm{N}, 4^{\circ} 42^{\prime} \mathrm{W} \\
\end{array}$ \\
\hline Main use & Recreation/agriculture & Water supply/agriculture \\
\hline Inundated area at pool level $\uparrow[\mathrm{ha}]$ & 145 & 277 \\
\hline Mean depth [m] & 4.2 & 5.5 \\
\hline Average annual air temp. $\left[{ }^{\circ} \mathrm{C}\right] \dagger$ & 17.4 & 16.7 \\
\hline Average annual rainfall $[\mathrm{mm}] \dagger$ & 563 & 693 \\
\hline Total phosphorous $\left[\mathrm{mg} \cdot \mathrm{L}^{-1}\right] \dagger$ & 0.08 & 0.10 \\
\hline Secchi transparency $[\mathrm{m}]$ & 1.42 & 1.34 \\
\hline Conductivity $\left[\mathrm{mS} \cdot \mathrm{cm}^{-1}\right] \dagger$ & 265.4 & 404.8 \\
\hline Chlorophyll a $\left[\mathrm{mg} \cdot \mathrm{L}^{-1}\right] \dagger$ & 6.4 & 21.7 \\
\hline \multicolumn{3}{|c|}{ Number of benthic macroinvertebrates } \\
\hline Decapoda & $0.8 \pm 0.1$ & $1.5 \pm 0.6$ \\
\hline Diptera larvae ${ }^{\S}$ & $13.8 \pm 5.4$ & $138.8 \pm 35.2$ \\
\hline Diptera pupae ${ }^{\S}$ & $6.5 \pm 4.2$ & $12.4 \pm 10.2$ \\
\hline Ephemeroptera nymphs & $112.3 \pm 32.3$ & $36.2 \pm 14.5$ \\
\hline Gastropoda & $0.1 \pm 0.1$ & $1.9 \pm 1.5$ \\
\hline Heteroptera & $30.5 \pm 17.3$ & $186.8 \pm 100.9$ \\
\hline Odonata nymphs & $0.7 \pm 0.3$ & $3.0 \pm 1.6$ \\
\hline Terrestrial insects & $0.2 \pm 0.2$ & $1.8 \pm 1.8$ \\
\hline Trichoptera larvae & $0.3 \pm 0.2$ & $2.1 \pm 1.1$ \\
\hline \multicolumn{3}{|c|}{ Abundance of zooplankton in net samples [No. of individuals $\cdot \mathrm{L}^{-1}$ ] } \\
\hline Bosmina & $0.7 \pm 0.6$ & $0.3 \pm 0.1$ \\
\hline Calanoida & $3.0 \pm 0.6$ & $2.2 \pm 0.4$ \\
\hline Chaoborus & $<$ & $<$ \\
\hline Cladocera (other) & $2.2 \pm 0.9$ & $5.6 \pm 3.6$ \\
\hline Cyclopoida & $<$ & $6.2 \pm 3.3$ \\
\hline Daphnia & $0.7 \pm 0.1$ & $10.7 \pm 2.0$ \\
\hline
\end{tabular}

Organisms' number and abundance given as mean \pm standard error of the mean; $\dagger$ Data obtained from the Portuguese Information System on Water Resources (www.snirh.pt); other information was obtained during fish sampling and from bibliography; ${ }^{\star}$ Assessed concurrently with fish sampling on five occasions from three timed (5 min) kick samples using a hand net (400 mm frame, $550 \mu \mathrm{m}$ mesh size); ${ }^{\S}$ Excluding Chaoborus; Zooplankton samples were taken near the dam on five occasions with a plankton net (200 $\mathrm{mm}$ diameter and $55 \mathrm{~mm}$ mesh size, three vertical hauls) and counted at the laboratory except the dominant rotifer; ${ }^{<}$Value below 0.01 . 
a particular centrarchid size-class were used in the evaluation of selection for that size-class.

Diet overlap (between different size-classes and species) was estimated in each reservoir and for each sampling period with Pianka's index (Pianka 1974). The index formula is:

$$
O_{i j}=\sum_{k=1}^{n} P_{i k} \cdot P_{j k} \cdot\left(\sqrt{\sum_{k=1}^{n} P_{i k}^{2}+\sum_{k=1}^{n} P_{j k}^{2}}\right)^{-1}
$$

where: $O_{i j}$ is the resource overlap between species $i$ and $j$, and $P_{i k}$ and $P_{j k}$ represent the proportions of the $k^{\text {th }}$ food category out of $\mathrm{n}$ such categories used by the $i^{\text {th }}$ and $j^{\text {th }}$ species.

This index varies from 0 , when there are no dietary items in common, to 1 , when the diet is the same. The significance test of each Pianka's index was generated comparing the observed overlap value with a distribution of expected overlap values based on a null model generated from 1000 repetitions using the RA3 algorithm available in the EcoSimR software*. The values observed were considered statistically different from the values of the null distribution if they were higher or lower than $95 \%$ of the simulated indices. An observed value significantly lower than the simulated index suggests low resource overlap, whereas an observed value significantly higher than the simulated index suggests that there is strong resource competition (Gotelli and Graves 1996).

Analysis of covariance (ANCOVA) was used to compare eviscerated weight between reservoirs (fixed factor), using fish length as the covariate (García-Berthou and Moreno-Amich 1993). The relative weight $W_{R}$ (Blackwell et al. 2000) was also determined to allow comparison of the fish condition in the studied reservoirs with the average condition of American populations of the same species. This index was developed in North America to compare the sampled fish weight to a standard weight $\left(W_{S}\right)$, reflecting the weight of a well fed fish. We used the following formula:

$$
W_{R}=100 \mathrm{TW} \times W_{S}^{-1}
$$

where: $W_{R}$ values between 95 and 105 indicating average body condition, whereas values above and below suggest, respectively, good and poor condition (Blackwell et al. 2000). $W_{S}$ were derived for each fish following the standard weight equations derived for North American populations by Henson unpublished**), in the case of bass, and Liao et al. (1995), in the case of pumpkinseed. Minimum sizes used in calculations were $50 \mathrm{~mm}$ for pumpkinseed and $150 \mathrm{~mm}$ in bass.

Before analysis, quantitative variables (except proportions) were log-transformed to improve homoscedasticity and linearity. Data analyses were performed using specialized software such as: Statistica (StatSoft), Canoco (ver. 4), and $\mathrm{R}$ software***.
All animal work was conducted according to Portuguese guidelines****. The necessary permits for fish sampling were obtained from the National Forest and Freshwater Fisheries Authority, Portuguese Ministry of Agriculture.

\section{RESULTS}

Fish collections. Pumpkinseed and bass accounted for the majority of fish collected in the littoral area of both reservoirs (proportion of each species in the total number of fish captured with electrofishing: in $\mathrm{MN}$, pumpkinseed $87.4 \%$ and bass $12.5 \%$; in TG, pumpkinseed $72.5 \%$ and bass $26.3 \%$ ), whereas pumpkinseeds were also frequently captured in trammel nets (proportion of pumpkinseed in the total number of fish collected with nets: in MN 74.8\% and in TG 46.2\%). Also other species were captured but they were rare and basically restricted to non-littoral areas: Cyprinus carpio Linnaeus, 1758; Luciobarbus comizo (Steindachner, 1864); Squalius pyrenaicus (Günther, 1868); Pseudochondrostoma willkommii (Steindachner, 1866); Cobitis paludica (de Buen, 1930); Gambusia holbrooki Girard, 1859; and Australoheros facetus (Jenyns, 1842). Pumpkinseeds were found from 22 to $173 \mathrm{~mm}$ in TL, and from 24 to $146 \mathrm{~mm}$ in TL, respectively, in MN and TG reservoirs. For bass, specimens collected ranged from 65 to $475 \mathrm{~mm}$ in TL in MN, and from 71 to $385 \mathrm{~mm}$ in TL in TG.

Diets. Overall, pumpkinseed diet was dominated by benthic macroinvertebrates and zooplankton (Fig. 1). Piscivory was also observed as well as the consumption of pumpkinseed eggs, items related to the terrestrial environment (mainly Hymenoptera) and vegetation (FO ranging from 2.4 to 13.6 for pumpkinseeds $>50 \mathrm{~mm}$ in TL). The diet of bass included fish and invertebrates in both reservoirs. Fish consumed by bass were mostly pumpkinseed (97.2\% of all fish prey in MN and $95.9 \%$ in TG), although bass and the native C. paludica and S. pyrenaicus were also found in stomach contents.

The graphical analysis exposed distinct feeding strategies between pumpkinseed size-classes. Diptera larvae, Ephemeroptera nymphs, and Daphnia were mostly eaten by fish $>50 \mathrm{~mm}$, whereas the consumption of Bosmina and Copepoda was only important for smaller specimens. There was an increased specialisation of a few specimens on some prey (chiefly Cladocera), together with the generalised consumption of occasional prey by most pumpkinseeds. For largemouth, the graphical analysis depicted a clear specialisation for fish prey with increasing size, with larger specimens eating almost exclusively fish and Decapoda. Differences between reservoirs in the diet of bass and pumpkinseed size-classes were also depicted in the Costello diagrams. For example, Ephemeroptera

\footnotetext{
${ }^{*}$ http://www.uvm.edu/ ngotelli/EcoSim/EcoSim.html.

** Henson J.C. 1991. Quantitative description and development of a species-specific standard growth form for largemouth bass, with application to the relative weight index. MSc thesis. Texas A\&M University, College Station, TX, USA.

${ }^{* * *}$ http://www.R-project.org.

**** INAG, Instituto da Água, I.P. 2008. Manual para a avaliação biológica da qualidade da água em sistemas fluviais segundo a Directiva Quadro da Água - Protocolo de amostragem e análise para a fauna piscícola. Lisboa: Ministério do Ambiente, do Ordenamento do Território e do Desenvolvimento Regional. Instituto da Água, I.P.
} 

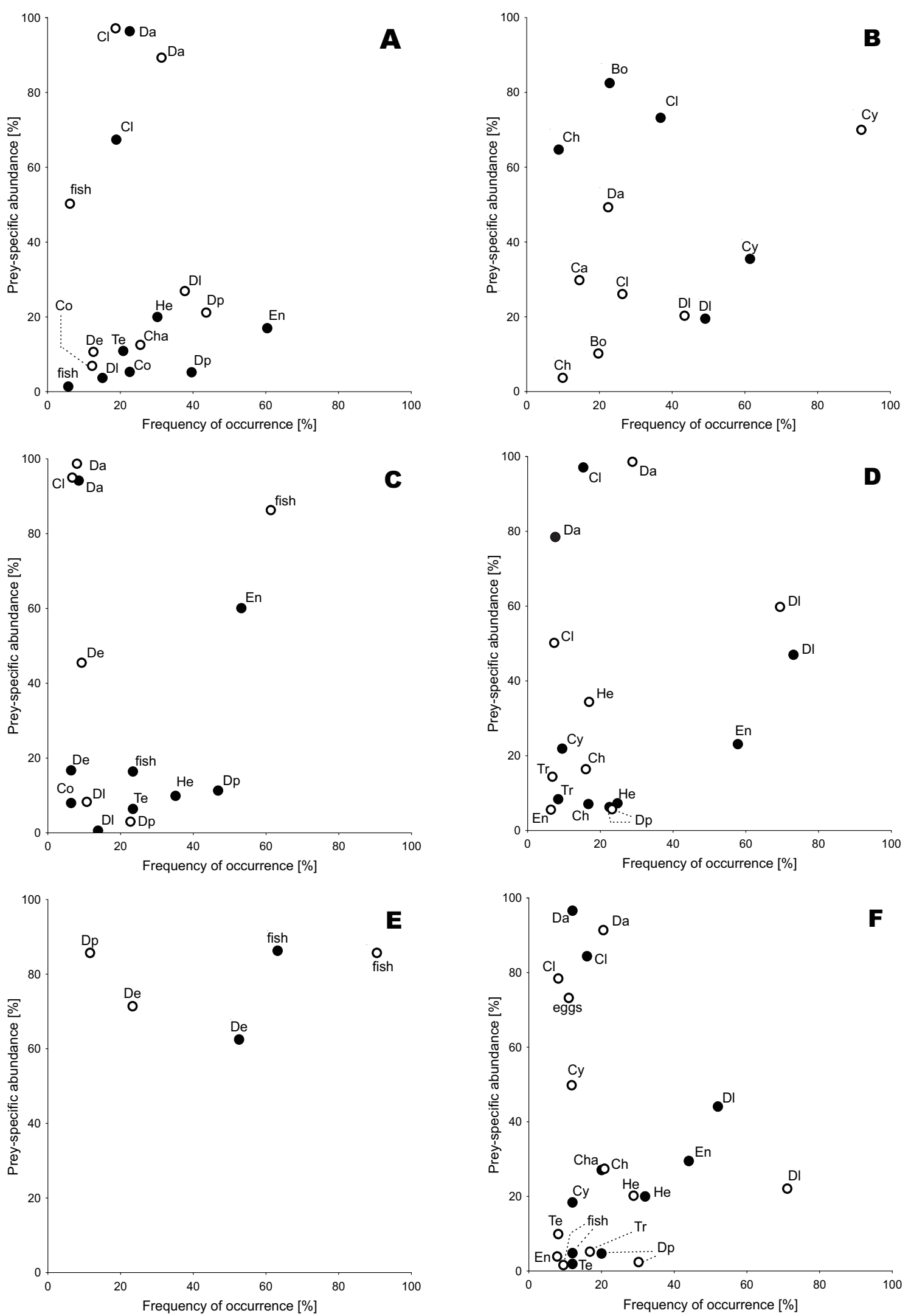

Fig. 1. Costello diagrams by species size-class and reservoir; Largemouth black bass, Micropterus salmoides: A small, C intermediate, E large; Pumpkinseed, Lepomis gibbosus: B small, D intermediate, F large; Black dot = Tapada Grande Reservoir, white dot $=$ Monte Novo Reservoir; Prey codes: $\mathrm{Bo}=$ Bosmina, $\mathrm{Ca}=$ Calanoida, $\mathrm{Ch}=$ Chydorus, $\mathrm{Cha}=$ Chaoborus, $\mathrm{Cl}=$ other Cladocera, $\mathrm{Co}=$ Copepoda, $\mathrm{Cy}=$ Cyclopoida, $\mathrm{Da}=$ Daphnia, $\mathrm{De}=$ Decapoda, $\mathrm{Dl}=$ Diptera larvae (except Chaoborus), $\mathrm{Dp}=$ Diptera pupae (except Chaoborus), En = Ephemeroptera nymps, $\mathrm{He}=$ Heteroptera, $\mathrm{Te}=$ Terrestrial insects, $\mathrm{Tr}=$ Trichoptera larvae; Only prey with frequency of occurrence $>5.0 \%$ are depicted. 
nymphs were mostly consumed in TG reservoir by both bass and pumpkinseed.

The first two dimensions of the correspondence analysis of prey proportions explained $23.7 \%$ and $25.2 \%$ of the dietary variance, respectively, for pumpkinseed and bass (Figs. 2 and 3). For pumpkinseed, the dietary gradients (stomach scores on the first two axes) varied with fish size (Wilk's Lambda $=0.73, F_{4 / 2094}=87.64, P<0.01$ ) and reservoir (Wilk's Lambda $=0.99, F_{2 / 1047}=5.38$, $P<0.01)$. For bass, dietary variation was related to sizeclass (Wilk's Lambda $=0.88, F_{4 / 620}=8.27, P<0.01$ ) and reservoir (Wilk's Lambda $=0.94, F_{2 / 310}=8.38, P<0.01$ ). The interaction reservoir $\times$ size-class was also significant (Wilk's Lambda $=0.93, F_{4 / 620}=4.03, P<0.01$ ), reflecting different patterns of bass dietary variation with size in the two reservoirs.

The consumption of all major prey items by pumpkinseed changed significantly with sampling period in the two reservoirs (Table 2). The consumption of several food categories by bass also changed with sampling period, but some prey were eaten more regularly, namely fish by larger bass. Fish was also eaten more regularly by the intermediate-size bass in $\mathrm{MN}$, but not in TG, where fish consumption was only important in the two last sampling periods.

The main invertebrates eaten by the pumpkinseeds were the most frequent and abundant and some of the diet differences between reservoirs could be related to variation in available prey (e.g., the distinct importance of Ephemeroptera nymphs, see Table 1). Despite the general relation between invertebrate abundance and importance in the diets, pumpkinseeds revealed variable selectivity for particular prey (Table 3). Diptera larvae were frequently preferred or eaten according to their abundance

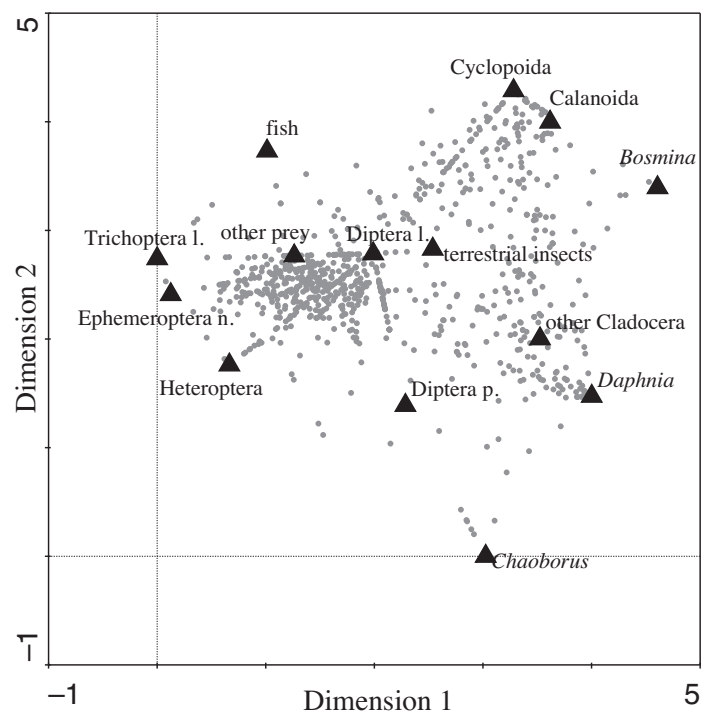

Fig. 2. Correspondence analysis biplot for the stomach contents (proportion prey number) of pumpkinseed, Lepomis gibbosus in Monte Novo and Tapada Grande reservoirs, Iberian Peninsula: food category and sample (stomachs) scores for the first and second dimensions in the two reservoirs. When preference for Diptera larvae decreased, the preference for other prey increased.

The selection for invertebrates by bass varied with time and among reservoirs, with Diptera larvae being always avoided (Table 4). The importance of pumpkinseed in the diet of intermediate bass was strongly related with availability of pumpkinseed with vulnerable sizes in both reservoirs: Pearson's $r$ between the number of pumpkinseeds per bass stomach and the (log-transformed) CPUE of pumpkinseed with vulnerable sizes (i.e., with a TL $<0.4 \times$ the mean TL of bass, after Hoyle and Keast 1987) $=0.94$, $P<0.01$ in $\mathrm{MN}$ and $0.89, P<0.01$ in TG. This relation was, however, not observed for larger bass $(P>0.10)$.

Diet overlap among pumpkinseed size-classes varied with sampling period, but it was often high in the two reservoirs (Table 5). Diet overlap among pumpkinseed size-classes and bass $(<200 \mathrm{~mm}$ in TL) was sometimes high in both reservoirs.

Population descriptors. The catch rate of pumpkinseed was significantly higher in $\mathrm{MN}$, particularly for larger fish, while catch rates of larger bass were higher in $\mathrm{MN}$ (Table 6). Bass grew slower in TG during the first years, but by age-3 length was comparable in the two reservoirs. Pumpkinseed grew significantly slower in TG.

The condition of pumpkinseed was higher in $\mathrm{MN}$ (ANCOVA of EW with reservoir as fixed factor and length as the covariate, $\left.F_{1 / 1052}=7.87, P<0.01\right)$. The condition of bass was also different between reservoirs (ANCOVA, $F_{1 / 287}=50.12, P<0.01$ ), but only for smaller fish (reservoir $\left.\times \mathrm{TL}, F_{1 / 287}=50.12, P<0.01\right)$. Based on $W_{R}$, the pumpkinseeds $(>50 \mathrm{~mm})$ in the two reservoirs had a body condition lower than the average condition of American populations, whereas bass $(>150 \mathrm{~mm})$ condition was lower than the average American condition only in TG reservoir.

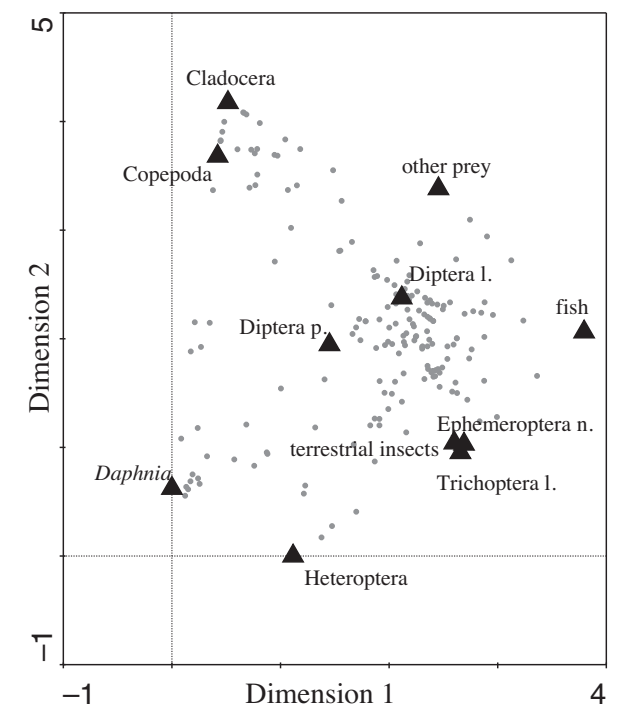

Fig. 3. Correspondence analysis biplot for the stomach contents (proportion prey number) largemouth black bass, Micropterus salmoides in Monte Novo and Tapada Grande reservoirs, Iberian Peninsula: food category and sample (stomachs) scores for the first and second dimensions 


\section{DISCUSSION}

Diets of pumpkinseed and bass in the reservoirs included some of the food items commonly eaten in their native and acclimatised ranges (Keast 1978, Hoyle and Keast 1987, Zapata and Granado-Lorencio 1993, GarcíaBerthou and Moreno-Amich 2000a, García-Berthou 2002, Almeida et al. 2009, Brown 2009). Notwithstanding, the sporadic consumption of fish by the pumpkinseeds has been rarely reported elsewhere (Rezsu and Specziár 2006). Note that we found entire fish in stomach contents and not fish remains, such as scales, whose ingestion could be independent of piscivory. In addition, the presence of macrophytes in pumpkinseed stomach contents was abnormally frequent in our study reservoirs, as other studies have reported much lower frequencies of occurrence (e.g., $<2 \%$, Bonar et al. 2004).
The increase in fish consumption and the corresponding decline of the invertebrate food component observed in the diet of bass with increasing body size parallel the dietary changes described in other studies (Brown 2009). In contrast, the typical dietary shifts associated with pumpkinseed growth in native environments (i.e., a rapid replacement of zooplankton by benthic macroinvertebrates as increasing size permits the handling of bigger, more profitable prey; Werner 1974) were unclear in the studied reservoirs, as zooplankton consumption remained high for a few larger specimens. The relevant consumption of gastropods by pumpkinseeds above $80 \mathrm{~mm}$ often described in native environments (Keast 1978, Mittelbach et al. 1992) was also not observed in the reservoirs, but it was likely related to the low abundance of this prey.

Table 2

Temporal variation in the mean number of prey/stomach for pumpkinseed, Lepomis gibbosus, and largemouth bass, Micropterus salmoides, in Monte Novo and Tapada Grande reservoirs, Iberian Peninsula

\begin{tabular}{|c|c|c|c|c|c|c|c|c|c|}
\hline \multicolumn{10}{|c|}{ Monte Novo PUMPKINSEED >100 mm in TL } \\
\hline & Apr 92 & Jun 92 & Aug 92 & Nov 92 & Mar 93 & Apr 93 & May 93 & Nov 93 & ANOVA \\
\hline Diptera larvae & $6.3 \pm 1.2$ & $6.2 \pm 0.7$ & $20.2 \pm 3.5$ & $15.8 \pm 3.1$ & $9.0 \pm 2.3$ & $7.0 \pm 1.3$ & $9.0 \pm 3.4$ & $1.8 \pm 0.5$ & $F_{7 / 521}=5.13$ \\
\hline Heteroptera & $0.8 \pm 0.2$ & $7.5 \pm 4.3$ & $6.1 \pm 2.5$ & $<$ & $2.9 \pm 1.7$ & $7.0 \pm 1.9$ & $9.4 \pm 6.3$ & 0 & $F_{7 / 521}=11.78$ \\
\hline Daphnia & $314.6 \pm 79.2$ & $11.2 \pm 8.6$ & $87.6 \pm 43.2$ & $69.0 \pm 26.4$ & $0.3 \pm 0.2$ & $208.5 \pm 40.1$ & $105.2 \pm 51.2$ & $0.5 \pm 0.4$ & $F_{7 / 521}=11.21$ \\
\hline Cladocera (other) & $8.9 \pm 3.2$ & $4.0 \pm 2.3$ & $32.6 \pm 21.2$ & $32.3 \pm 15.1$ & $3.4 \pm 1.7$ & 0 & $1.6 \pm 0.7$ & 0 & $F_{7 / 521}=4.47$ \\
\hline Copepoda & $4.7 \pm 2.3$ & $4.1 \pm 3.0$ & $<$ & $32.5 \pm 16.2$ & $5.2 \pm 3.3$ & $0.8 \pm 0.3$ & $0.6 \pm 0.4$ & $2.3 \pm 1.5$ & $F_{7 / 521}=6.79$ \\
\hline Fish & $<$ & $<$ & $0.3 \pm 0.1$ & $<$ & 0 & 0 & 0 & $0.3 \pm 0.1$ & $F_{7 / 521}=5.18$ \\
\hline \multicolumn{10}{|c|}{ Monte Novo PUMPKINSEED 50-100 $\mathrm{mm}$ in TL } \\
\hline Diptera larvae & $12.3 \pm 1.7$ & $13.3 \pm 3.1$ & $30.0 \pm 6.9$ & $2.3 \pm 0.6$ & $0.5 \pm 0.4$ & $11.2 \pm 4.1$ & $23.2 \pm 3.5$ & $0.6 \pm 0.4$ & $F_{7 / 243}=11.31$ \\
\hline Heteroptera & 0 & $3.0 \pm 1.5$ & $0.3 \pm 0.3$ & 0 & 0 & $3.3 \pm 1.0$ & $3.5 \pm 1.2$ & 0 & $F_{7 / 243}=8.82$ \\
\hline Daphnia & $115.2 \pm 72.1$ & 0 & $26.7 \pm 20.5$ & 0 & 0 & $0.2 \pm 0.2$ & $1.7 \pm 0.7$ & 0 & $F_{7 / 243}=2.38$ \\
\hline Cladocera (other) & $0.7 \pm 0.3$ & 0 & $0.1 \pm 0.1$ & $10.1 \pm 5.3$ & 0 & 0 & 0 & $1.3 \pm 0.9$ & $F_{7 / 243}=4.56$ \\
\hline Copepoda & $3.8 \pm 1.2$ & 0 & $5.7 \pm 4.5$ & $2.1 \pm 1.0$ & 0 & $<$ & $<$ & $21.9 \pm 11.3$ & $F_{7 / 243}=3.31$ \\
\hline \multicolumn{10}{|c|}{ Tapada Grande PUMPKINSEED 50-100 mm in TL } \\
\hline Diptera larvae & $1.6 \pm 0.5$ & $5.3 \pm 1.0$ & $0.8 \pm 0.3$ & $2.2 \pm 1.8$ & $16.5 \pm 2.9$ & $18.2 \pm 3.4$ & $12.0 \pm 2.2$ & $5.4 \pm 1.6$ & $F_{7 / 316}=13.80$ \\
\hline Ephemeroptera nymph & $0.9 \pm 0.6$ & $3.4 \pm 0.4$ & $3.8 \pm 1.2$ & $1.2 \pm 0.8$ & $2.7 \pm 0.6$ & $9.0 \pm 1.7$ & $2.3 \pm 0.3$ & $0.1 \pm 0.1$ & $F_{7 / 316}=11.24$ \\
\hline Daphnia & $9.0 \pm 6.3$ & $2.2 \pm 1.8$ & $21.7 \pm 9.3$ & $101.0 \pm 53.2$ & $3.1 \pm 2.7$ & 0 & $0.9 \pm 0.8$ & $1.9 \pm 1.7$ & $F_{7 / 316}=5.27$ \\
\hline Cladocera (other) & $133.0 \pm 76.7$ & $1.9 \pm 0.6$ & $73.9 \pm 26.7$ & $160.0 \pm 137.0$ & $0.2 \pm 0.1$ & $6.8 \pm 0.1$ & 0 & $59.0 \pm 15.0$ & $F_{7 / 316}=7.64$ \\
\hline Copepoda & $4.5 \pm 2.7$ & $0.6 \pm 0.3$ & $1.7 \pm 1.3$ & 0 & $0.4 \pm 0.2$ & $0.2 \pm 0.2$ & 0 & $14.4 \pm 5.2$ & $F_{7 / 316}=10.65$ \\
\hline \multicolumn{10}{|c|}{ Monte Novo LARGEMOUTH BASS $>200 \mathrm{~mm}$ in TL } \\
\hline Fish & $0.5 \pm 0.2$ & $1.0 \pm 0.2$ & $2.0 \pm 0.3$ & $1.1 \pm 0.1$ & $0.6 \pm 0.2$ & $0.6 \pm 0.2$ & $1.1 \pm 0.4$ & $1.7 \pm 0.3$ & $F_{7 / 48}=2.10$, n.s. \\
\hline Decapoda & $0.7 \pm 0.3$ & 0 & 0 & 0 & 0 & $0.4 \pm 0.2$ & $0.3 \pm 0.2$ & 0 & $F_{7 / 48}=1.09$, n.s. \\
\hline \multicolumn{10}{|c|}{ Monte Novo LARGEMOUTH BASS $100-200 \mathrm{~mm}$ in TL } \\
\hline Fish & - & $0.6 \pm 0.5$ & $1.0 \pm 0.8$ & $0.2 \pm 0.3$ & $0.1 \pm 0.2$ & $1.0 \pm 1.0$ & $0.8 \pm 0.6$ & $1.3 \pm 0.5$ & $F_{7 / 71}=19.01$ \\
\hline Diptera pupae & - & $3.5 \pm 3.2$ & $0.8 \pm 0.9$ & $1.0 \pm 1.1$ & $4.1 \pm 1.2$ & $1.7 \pm 1.9$ & 0 & 0 & $F_{7 / 71}=7.55$ \\
\hline Cladocera & - & $126.6 \pm 115.6$ & 0 & $6.3 \pm 8.2$ & $226.5 \pm 210.5$ & 0 & $75.0 \pm 68.2$ & 0 & $F_{7 / 71}=25.72$ \\
\hline \multicolumn{10}{|c|}{ Tapada Grande LARGEMOUTH BASS $>200 \mathrm{~mm}$ in TL } \\
\hline Fish & $2.0 \pm 0.7$ & $1.0 \pm 0.1$ & - & - & $1.0 \pm 0.1$ & $0.6 \pm 0.2$ & $1.0 \pm 0.1$ & $1.1 \pm 0.3$ & $F_{7 / 32}=1.74$, n.s. \\
\hline Decapoda & $0.5 \pm 0.2$ & 0 & - & - & $0.2 \pm 0.1$ & $0.3 \pm 0.1$ & $1.0 \pm 0.2$ & $0.6 \pm 0.1$ & $F_{7 / 32}=3.81$ \\
\hline \multicolumn{10}{|c|}{ Tapada Grande LARGEMOUTH BASS $100-200 \mathrm{~mm}$ in TL } \\
\hline Fish & 0 & $<$ & $0.1 \pm 0.1$ & $0.1 \pm 0.1$ & 0 & 0 & $0.9 \pm 0.3$ & $1.0 \pm 0.2$ & $F_{7 / 102}=24.17$ \\
\hline Ephemeroptera nymph & $0.2 \pm 0.2$ & $2.1 \pm 1.3$ & $1.1 \pm 0.9$ & $1.4 \pm 1.3$ & $13.0 \pm 11.2$ & $76.4 \pm 31.3$ & $12.1 \pm 8.7$ & 0 & $F_{7 / 102}=2.75$ \\
\hline Diptera pupae & 0 & $3.0 \pm 1.2$ & $0.1 \pm 0.5$ & $1.3 \pm 0.4$ & $1.7 \pm 0.6$ & $4.0 \pm 81.0$ & $0.8 \pm 1.2$ & 0 & $F_{7 / 102}=1.61$, n.s. \\
\hline Heteroptera & 0 & $<$ & $0.5 \pm 0.2$ & $0.9 \pm 0.7$ & $3.9 \pm 1.0$ & $2.8 \pm 0.8$ & $0.4 \pm 0.2$ & 0 & $F_{7 / 102}=12.27$ \\
\hline Terrestrial insects & 0 & $0.2 \pm 0.2$ & $3.7 \pm 2.1$ & $0.4 \pm 0.3$ & $0.2 \pm 0.1$ & $0.9 \pm 0.8$ & $0.3 \pm 0.2$ & 0 & $F_{7 / 102}=0.97$, n.s. \\
\hline Cladocera & 0 & $190.6 \pm 75.6$ & $72.4 \pm 41.1$ & $2.4 \pm 5.6$ & 0 & 0 & 0 & 0 & $F_{7 / 102}=4.20$ \\
\hline
\end{tabular}

ANOVA results comparing temporal variation in the number of prey/stomach are given; All significant $(P<0.01)$, except were noticed (non-significant, n.s.). Only the dominant size-classes and primary prey are presented; $<$ value below 0.1 . 
Table 3

Manly-Chesson (a) for size-classes of pumpkinseed, Lepomis gibbosus, feeding on benthic macroinvertebrates and zooplankton in Monte Novo and Tapada Grande reservoirs, Iberian Peninsula

\begin{tabular}{|c|c|c|c|c|c|}
\hline & Aug 92 & Nov 92 & Feb 93 & May 93 & Nov 93 \\
\hline \multicolumn{6}{|c|}{ MONTE NOVO Pumpkinseed $>100 \mathrm{~mm}$ in TL } \\
\hline $\mathrm{m}^{-1}$ & 0.14 & 0.13 & 0.17 & 0.14 & 0.25 \\
\hline Decapoda & $<$ & 0 & 0 & & \\
\hline Diptera larvae & 0.15 & 0.09 & 0.27 & 0.35 & 0.85 \\
\hline Diptera pupae & 0.04 & 0.08 & 0.27 & 0.31 & $<$ \\
\hline Heteroptera & 0.58 & $<$ & 0.12 & $<$ & 0 \\
\hline Ephemerotera nymph & $<$ & 0 & 0.07 & 0.14 & \\
\hline Trichoptera larvae & 0.02 & 0.77 & 0.27 & 0.02 & 0 \\
\hline Gastropoda & & 0.04 & & 0 & \\
\hline Terrestrial insects & 0.20 & 0 & & 0.18 & \\
\hline $\mathrm{m}^{-1}$ & & 0.20 & 0.20 & 0.25 & 0.20 \\
\hline Daphnia & & 0.04 & 0.67 & 0.96 & 0.10 \\
\hline Cladocera (other) & & 0.04 & 0.18 & 0 & 0 \\
\hline Cyclops & & 0.02 & 0.05 & 0.04 & 0.86 \\
\hline Calanoida & & $<$ & $<$ & $<$ & 0.04 \\
\hline Chaoborus & & 0.89 & 0.09 & & 0 \\
\hline \multicolumn{6}{|c|}{ MONTE NOVO Pumpkinseed $50-100 \mathrm{~mm}$ in TL } \\
\hline $\mathrm{m}^{-1}$ & 0.20 & 0.20 & 0.20 & 0.25 & 0.20 \\
\hline Diptera larvae & 0.35 & 0.15 & 0.08 & 0.35 & 0.07 \\
\hline Diptera pupae & 0.44 & 0.03 & 0.60 & 0.08 & $<$ \\
\hline Heteroptera & 0.18 & 0 & 0 & $<$ & 0 \\
\hline Ephemerotera nymph & 0 & 0 & 0.32 & 0.57 & 0.01 \\
\hline Trichoptera larvae & 0 & 0.92 & 0 & & $<$ \\
\hline $\mathrm{m}^{-1}$ & & 0.20 & 0.20 & & 0.20 \\
\hline Daphnia & & 0 & 0.68 & & 0 \\
\hline Cladocera (other) & & 0.16 & 0 & & 0.59 \\
\hline Cyclops & & 0.02 & 0.04 & & 0.41 \\
\hline Calanoida & & 0.49 & 0 & & $<$ \\
\hline Chaoborus & & 0.32 & 0 & & 0 \\
\hline \multicolumn{6}{|c|}{ TAPADA GRANDE Pumpkinseed $>50 \mathrm{~mm}$ in TL } \\
\hline $\mathrm{m}^{-1}$ & 0.20 & 0.17 & 0.25 & 0.20 & 0.33 \\
\hline Diptera larvae & 0.19 & 0.29 & 0.85 & 0.62 & 0.82 \\
\hline Diptera pupae & 0.04 & 0.30 & 0.03 & 0.02 & 0.17 \\
\hline Heteroptera & 0.17 & 0.31 & $<$ & 0.02 & \\
\hline Ephemeroptera nymph & 0.05 & 0.01 & 0.11 & 0.14 & 0.01 \\
\hline Trichoptera larvae & 0.47 & 0 & & & \\
\hline Terrestrial insects & & 0 & & 0.16 & \\
\hline $\mathrm{m}^{-1}$ & & 0.17 & 0.25 & 0.17 & 0.20 \\
\hline Daphnia & & 0.17 & 0.58 & 0 & 0.01 \\
\hline Bosmina & & 0 & & 0 & 0.28 \\
\hline Cladocera $\dagger$ & & 0.79 & 0 & $<$ & 0.08 \\
\hline Cyclops & & 0 & 0.41 & $<$ & 0.51 \\
\hline Calanoida & & 0 & 0.01 & $<$ & 0.12 \\
\hline Chaoborus & & 0.03 & & 0.99 & \\
\hline
\end{tabular}

The index was determined for size-classes with at least five specimens in a particular size-class/sampling occasion; The reciprocal of the $(\mathrm{m})$ number of prey in each sampling location/date $\left(\mathrm{m}^{-1}\right)$ represents neutral selection Values $>\mathrm{m}^{-1}$ indicate positive selection and values $<\mathrm{m}^{-1}$ indicate avoidance; $<$ a value below 0.01 . 
Table 4

Manly-Chesson (a) for size-classes of largemouth bass, Micropterus salmoides, feeding on benthic macroinvertebrates and zooplankton in Monte Novo and Tapada Grande reservoirs, Iberian Peninsula

\begin{tabular}{|c|c|c|c|c|c|}
\hline & Aug 92 & Nov 92 & Feb 93 & May 93 & Nov 93 \\
\hline \multicolumn{6}{|c|}{ MONTE NOVO Largemouth bass $100-200 \mathrm{~mm}$ in TL } \\
\hline $\mathrm{m}^{-1}$ & - & 0.14 & 0.17 & 0.17 & - \\
\hline Decapoda & - & 0.62 & 0.70 & 0 & - \\
\hline Diptera larvae & - & 0.01 & $<$ & 0 & - \\
\hline Diptera pupae & - & 0.36 & 0.10 & 0.14 & - \\
\hline Heteroptera & - & 0 & 0 & $<$ & - \\
\hline Ephemeroptera nymph & - & 0 & 0 & 0.43 & - \\
\hline Terrestrial insects & - & 0 & & 0.43 & - \\
\hline Odonata nymph & - & 0 & 0.20 & & - \\
\hline $\mathrm{m}^{-1}$ & - & 0.33 & 0.33 & 0.33 & - \\
\hline Daphnia & - & 0 & 0.99 & 0 & - \\
\hline Cladocera (other) & - & 0.73 & 0 & 0 & - \\
\hline Chaoborus & - & 0.27 & $<$ & 0 & - \\
\hline \multicolumn{6}{|c|}{ MONTE NOVO Largemouth bass $<100 \mathrm{~mm}$ in TL } \\
\hline $\mathrm{m}^{-1}$ & - & 0.20 & 0.17 & - & - \\
\hline Decapoda & - & 0.04 & 0 & - & - \\
\hline Diptera larvae & - & $<$ & 0.06 & - & - \\
\hline Diptera pupae & - & 0.96 & 0.46 & - & - \\
\hline Heteroptera & - & $<$ & 0 & - & - \\
\hline Ephemeroptera nymph & - & 0 & 0.07 & - & - \\
\hline Trichoptera larvae & - & & 0.41 & - & - \\
\hline $\mathrm{m}^{-1}$ & - & 0.25 & 0.25 & - & - \\
\hline Daphnia & - & 0.39 & 0 & - & - \\
\hline Cladocera (other) & - & 0.32 & 0 & - & - \\
\hline Cyclops & - & $<$ & 0 & - & - \\
\hline Chaoborus & - & 0.26 & 0 & - & - \\
\hline \multicolumn{6}{|c|}{ TAPADA GRANDE Largemouth bass $100-200 \mathrm{~mm}$ in TL } \\
\hline $\mathrm{m}^{-1}$ & 0.13 & 0.13 & 0.14 & 0.14 & 0.25 \\
\hline Decapoda & 0 & 0.02 & 0 & 0.01 & 1.00 \\
\hline Diptera larvae & 0.01 & 0 & 0.04 & $<$ & 0 \\
\hline Diptera pupae & 0.02 & 0.07 & 0.11 & 0.06 & 0 \\
\hline Heteroptera & 0.04 & 0.07 & 0.03 & $<$ & \\
\hline Ephemeroptera nymph & 0 & $<$ & 0.42 & 0.30 & 0 \\
\hline Trichoptera larvae & 0 & 0.09 & 0.02 & 0 & \\
\hline Terrestrial insects & 0.92 & 0.09 & 0.12 & 0.57 & \\
\hline Odonata nymph & 0 & 0.65 & & & \\
\hline $\mathrm{m}^{-1}$ & & 0.33 & 0.33 & 0.33 & 0.33 \\
\hline Daphnia & & 0 & 0 & 0 & 0 \\
\hline Cladocera (other) & & 1.00 & 0 & 0 & 0 \\
\hline Cyclops & & 0 & 0 & 0 & 0 \\
\hline \multicolumn{6}{|c|}{ TAPADA GRANDE Largemouth bass $<100 \mathrm{~mm}$ in TL } \\
\hline $\mathrm{m}^{-1}$ & 0.17 & - & 0.17 & - & - \\
\hline Decapoda & 0 & - & 0.16 & - & - \\
\hline Diptera larvae & 0.06 & - & 0 & - & - \\
\hline Diptera pupae & 0 & - & 0.14 & - & - \\
\hline Heteroptera & 0 & - & 0.03 & - & - \\
\hline Ephemeroptera nymph & $<$ & - & 0.68 & - & - \\
\hline Trichoptera larvae & 0.93 & - & 0 & - & - \\
\hline
\end{tabular}

The index was determined for size-classes with at least five specimens in a particular size-class/sampling occasion; The reciprocal of the $(\mathrm{m})$ number of prey in a particular sampling location/date $\left(\mathrm{m}^{-1}\right)$ represents neutral selection; Values $>\mathrm{L} \times \mathrm{m}^{-1}$ indicate positive selection and values $<\mathrm{L} \times \mathrm{m}^{-1}$ indicate avoidance; $<$ a value below 0.01 . 
Constrained by each species morphology (bass is changing prey according to availability and vulnerability. a swift-striking predator more adapted to water column For example, Diptera larvae were likely more vulnerable and surface prey whereas pumpkinseed is adapted to feed- to pumpkinseed than other benthic prey, like the active ing on the bottom), both pumpkinseed and bass demon- swimmers Heteroptera, whereas Diptera pupae and terresstrated an overall dietary opportunism, feeding on the trial insects could have been more accessible to bass. most frequent and abundant prey in each reservoir and

Table 5

Piankas's index of overlap for size-classes of largemouth bass, Micropterus salmoides and the pumpkinseed, Lepomis gibbosus sampled in Monte Novo and Tapada Grande reservoirs, Iberian Peninsula

\begin{tabular}{lcccc}
\hline Date & $\begin{array}{c}\text { MN pumpkinseed size- } \\
\text { classes }\end{array}$ & $\begin{array}{c}\text { MN pumpkinseed-bass } \\
(<200 \mathrm{~mm})\end{array}$ & $\begin{array}{c}\text { TG pumpkinseed size- } \\
\text { classes }\end{array}$ & $\begin{array}{c}\text { TG pumpkinseed-bass } \\
(<200 \mathrm{~mm})\end{array}$ \\
\cline { 2 - 5 } April 92 & $0.97>$ & $0.98>$ & $0.95>$ & $0.81>$ \\
June 92 & $0.51>$ & $0.40>$ & $0.37>$ & $0.60>$ \\
August 92 & $0.29>$ & $0.39>$ & $\dagger$ & $0.96>$ \\
November 92 & $0.36>$ & $0.59>$ & $0.34>$ & n.s. \\
March 93 & $0.34>$ & $0.30>$ & $0.76>$ & $0.35>$ \\
April 93 & $0.06<$ & n.s. & $0.53>$ & $0.46>$ \\
May 93 & $0.82>$ & n.s. & $0.94>$ & $0.36>$ \\
November 93 & $0.89>$ & $0.46>$ & $0.83>$ & $0.28>$ \\
\hline
\end{tabular}

$\mathrm{MN}=$ Monte Novo, $\mathrm{TG}=$ Tapada Grande; $>$ value significantly higher than the value obtained under a full model $(P<0.05)$; $<$ value significantly lower than the value obtained under a full model $(P<0.05)$; n.s. = non-significant overlap value; $\dagger$ A single size-class sampled.

Table 6

Characteristics of the largemouth black bass, Micropterus salmoides, and the pumpkinseed, Lepomis gibbosus, populations sampled in Monte Novo and Tapada Grande reservoirs, Iberian Peninsula

\begin{tabular}{|c|c|c|c|c|}
\hline & & Tapada Grande & Monte Novo & ANOVA \\
\hline \multirow{9}{*}{ 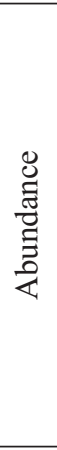 } & Catch E bass & $0.32 \pm 0.09(8)$ & $0.33 \pm 0.11(8)$ & $F_{1 / 14}=0.03$ \\
\hline & Catch E pumpkinseed & $1.23 \pm 0.34(8)$ & $2.81 \pm 1.12(8)$ & $F_{1 / 14}=9.05 \dagger$ \\
\hline & Catch E bass $>200 \mathrm{~mm}$ & $0.03 \pm 0.01(8)$ & $0.11 \pm 0.05(8)$ & $F_{1 / 14}=4.91 \dagger \dagger$ \\
\hline & Catch E bass $\leq 200 \mathrm{~mm}$ & $0.29 \pm 0.12(8)$ & $0.22 \pm 0.05(8)$ & $F_{1 / 14}=0.38$ \\
\hline & Catch $\mathrm{E}$ for pumpkinseed $>100 \mathrm{~mm}$ & $0.08 \pm 0.03(8)$ & $1.65 \pm 0.32(8)$ & $F_{1 / 14}^{1 / 14}=9.97 \dagger$ \\
\hline & Catch E for pumpkinseed $50-100 \mathrm{~mm}$ & $0.82 \pm 0.19(8)$ & $0.40 \pm 0.11(8)$ & $F_{1 / 14}^{1 / 14}=3.04$ \\
\hline & Catch E pumpkinseed $\leq 50 \mathrm{~mm}$ & $0.33 \pm 0.24(8)$ & $0.76 \pm 0.56(8)$ & $F_{1 / 14}=2.97$ \\
\hline & Catch N bass & $0.07 \pm 0.06(8)$ & $0.30 \pm 0.11(8)$ & $F_{1 / 14}=2.86$ \\
\hline & Catch N pumpkinseed & $2.32 \pm 1.22(8)$ & $6.34 \pm 1.05(8)$ & $F_{1 / 14}=4.92 \dagger \dagger$ \\
\hline \multirow{8}{*}{$\begin{array}{l}\text { 节 } \\
\text { ல }\end{array}$} & Bass TL age $1[\mathrm{~mm}]$ & $128.6 \pm 2.12(98)$ & $161.2 \pm 4.11(91)$ & $F_{1 / 187}=78.51 \dagger$ \\
\hline & Bass TL age $2[\mathrm{~mm}]$ & $206.9 \pm 9.81(158)$ & $248.0 \pm 7.76(113)$ & $F_{1 / 269}=64.38 \dagger$ \\
\hline & Bass TL age $3[\mathrm{~mm}]$ & $358.3 \pm 10.2(12)$ & $339.6 \pm 8.7(24)$ & $F_{1 / 34}=3.49$ \\
\hline & Bass TL age $4[\mathrm{~mm}]$ & $405.0 \pm 6.0(6)$ & $400.1 \pm 4.0(9)$ & $F_{1 / 13}^{1 / 34}=2.18$ \\
\hline & Pumpkinseed TL age $1[\mathrm{~mm}]$ & $60.0 \pm 1.27(236)$ & $73.1 \pm 3.82(258)$ & $F_{1 / 492}=17.86 \dagger$ \\
\hline & Pumpkinseed TL age $2[\mathrm{~mm}]$ & $81.1 \pm 0.99(82)$ & $103.5 \pm 1.18(73)$ & $F_{1 / 153}=69.13 \dagger$ \\
\hline & Pumpkinseed TL age $3[\mathrm{~mm}]$ & $94.0 \pm 1.02(67)$ & $121.4 \pm 1.54(85)$ & $F_{1 / 150}=71.05 \dagger$ \\
\hline & Pumpkinseed TL age $4[\mathrm{~mm}]$ & $102.3 \pm 1.56(26)$ & $134.0 \pm 1.35(40)$ & $F_{1 / 64}=92.15 \dagger$ \\
\hline \multirow{2}{*}{ U } & $W_{R}$ for bass $>150 \mathrm{~mm}$ & $91.90 \pm 0.63(152)$ & $111.27 \pm 0.71(137)$ & $F_{1 / 287}=7.71 \dagger$ \\
\hline & $W_{R}$ for pumpkinseed $>50 \mathrm{~mm}$ & $80.50 \pm 0.69(289)$ & $87.98 \pm 0.48(765)$ & $F_{1 / 1052}=11.15 \dagger$ \\
\hline
\end{tabular}

Catch $\mathrm{E}=$ catch per min of electrofishing; Catch $\mathrm{N}=$ catch per $100 \mathrm{~m}^{2}$ non-littoral trammel net; $\mathrm{BC}=$ Body condition; Fish age in years; $W_{R}=$ Relative Weight; Values are mean \pm standard error of the mean (number); ANOVA results are comparisons between the two reservoirs; $\uparrow P<0.01, \dagger \uparrow P<0.05$. 
The abundance of fish with vulnerable dimensions strongly conditioned the diet of largemouth bass. In particular, intermediate-size bass took fish (mostly pumpkinseed) if available in vulnerable sizes and used other, smaller prey, more frequently where and when fish were less numerous. In contrast, the higher and more constant availability of vulnerable pumpkinseeds found by larger bass in the reservoirs may have resulted in the lack of relation between the abundance of pumpkinseed and its consumption by bass above $200 \mathrm{~mm}$. The other fish species present in the reservoirs with some importance, i.e., large-sized cyprinids Luciobarbus comizo and Pseudochondrostoma willkommii, were not vulnerable to bass since their populations are composed of relatively large individuals that reproduce outside the reservoirs in tributary streams (Godinho unpublished). Nevertheless, two native species were found in bass stomach contents, including the endangered small-sized cyprinid Squalius spp. Other investigations have shown bass to prefer Iberian native soft-bodied cyprinids to Lepomis spp. (Godinho and Ferreira 2006) and have related its introduction to the collapse of native fish assemblages in some of the few natural lakes in the Iberian Peninsula (GarcíaBerthou and Moreno-Amich 2000b). Small-sized cyprinids were found to be absent or rare in the presence of both bass and pumpkinseed in a set of Iberian reservoirs (Clavero et al. 2013), but no data on the fish assemblages of the two studied reservoirs was available before the present investigation to allow a clearer assessment of the effect of the introduction of the two centrarchids on the $\mathrm{MN}$ and $\mathrm{TG}$ fish assemblages.

In the absence of preferred prey several fish species take less profitable food and the maintenance of zooplankton in the diet of larger pumpkinseeds, but also of other uncommon prey like fish, could have represented the most profitable feeding strategy available in the reservoirs, as frequent water level fluctuations should constrain the overall availability of littoral benthic prey, including gastropods (Fontoura and Paw 1991). Although experimental studies suggest that pumpkinseed above $80 \mathrm{~mm}$ use Daphnia with less profitability than other prey, such as gastropods (Mittelbach 1984), some investigations conducted in North America have showed that adult pumpkinseeds can eat large quantities of zooplankon in lakes without the bluegill or other zooplanktivorous species, sometimes developing a pelagic morphotype (Robinson et al. 1993, 2000). The adult bluegill is morphologically better adapted than the pumpkinseed to eat zooplankton and when the two species are sympatric the former usually precludes the utilisation of zooplankton by the pumpkinseed (Osenberg et al. 1988, 1992, Mittelbach et al. 1992). Interestingly, the phenotypic plasticity observed in some American pumpkinseed populations (littoral and pelagic morphotypes) has been found in some Iberian reservoirs (Bhagat et al. 2006, Vila-Gispert et al. 2007) and could be related to the patterns of zooplankton use observed in this study. In the studied reservoirs as in the majority of Iberian environments the absence of other zoo- planktivorous species may facilitate the use of zooplankton by the pumpkinseeds (Braband and Saltveit 1989).

The inclusion of zooplankton in the diet of larger pumpkinseed likely contributed to the maintenance of abundant populations in the reservoirs; catch rates were comparable to catch rates reported for bluegill (the more abundant Lepomis species due to its zooplankton utilization) in American lakes and reservoirs (Gabelhouse 1987, Hardin and Connor 1992, Dumont and Dennis 1997). The high pumpkinseed abundance was, however, linked to low individual growth of larger individuals, when compared with the growth described for several American populations (Fox et al. 2007), and poor condition, particularly in the reservoir with few resources. Conversely, pumpkinseed growth at ages 1 and 2 years was fast and comparable to the growth reported for some American populations living in warmer waters (Fox et al. 2007), suggesting that limitations in profitable food resources could have been more pronounced for larger pumpkinseeds than for smaller ones.

For bass, growth in the reservoirs was comparable to the growth reported at similar latitudes in North America (Beamesderfer and North 1995) but body condition was lower for smaller individuals in the reservoir with lower resources. The delayed transition to piscivory registered in TG may have constrained the survival of bigger individuals, as the littoral catch rate for larger specimens was lower than most catch rates reported in North America (Gabelhouse 1987, Hardin and Connor 1992, Dumont and Dennis 1997).

High resource overlap could be indicative of exploitative competition in animal communities when associated with measurable consequences at the individual and population levels, such as reductions in growth and abundance (Hodgson et al. 1991, He et al. 1994). Although resource overlap was frequently high in the two reservoirs between bass and pumpkinseed and between different pumpkinseed size-classes, the contrasting population characteristics were observed in the two reservoirs, i.e., in TG (lower food availability) vs. MN (higher food availability):

- The lower growth and worst condition of smaller bass and all pumpkinseeds;

- The lower abundance of pumpkinseed and larger bass.

The above characteristics seem to support the occurrence of food competition between pumpkinseed size classes and between smaller bass and pumpkinseed, somewhat mirroring to biotic relations reported for the bass/bluegill association in American ponds and small reservoirs.

Reservoirs present higher environmental variability than natural lakes (Wetzel 1990), something that should limit the overall importance of biotic interactions (Wahl et al. 1995), but the characteristics of studied reservoirs (and of southern Iberian reservoirs in general), with high temperatures (high fish metabolism), presence of simple fish communities without typical zooplanktivores (leaving the pelagic habitat empty) and limitations in littoral invertebrates abundance (related to the water level fluctuations due to reservoir water use), likely contributed to the observed patterns in resource use and overlap. 


\section{ACKNOWLEDGEMENTS}

The presently reported study was funded by the Portuguese Ministry of Agriculture. Thanks are due to the following colleagues for their contribution during extensive field work: Jorge Bochechas, Teresa Cravo, Lurdes Martins, Maria Castro, and Guilherme Kalupeteka.

\section{REFERENCES}

Almeida D., Almodóvar A., Nicola G.G., Elvira B. 2009. Feeding tactics and body condition of two introduced populations of pumpkinseed Lepomis gibbosus: taking advantages of human disturbances? Ecology of Freshwater Fish 18 (1): 15-23. DOI: 10.1111/j.1600-0633.2008.00317.x

Amundsen P.-A., Gabler H.-M., Staldvik F.J. 1996. A new approach to graphical analysis of feeding strategy from stomach contents data - modification of the Costello (1990) method. Journal of Fish Biology 48 (4): 607-614. DOI: $10.1111 /$ j.1095-8649.1996.tb01455.x

Arendt J.D., Wilson D.S. 1999. Countergradient selection for rapid growth in pumpkinseed sunfish, disentangling ecological and evolutionary effects. Ecology 80 (8): 2793-2798. DOI: 10.1890/0012-9658(1999)080[2793:CSFRGI]2.0.CO;2

Bagenal T.B., Tesch F.W. 1978. Age and growth. Pp. 101-136. In: Bagenal T. (ed.) Methods for assessment of fish production in fresh waters. IBP handbook 3. Blackwell SciencePublications, Oxford, UK.

Beamesderfer R.C.P., North J.A. 1995. Growth, natural mortality, and predicted response to fishing for largemouth bass and smallmouth bass populations in North America. North American Journal of Fisheries Management 15 (3): 688-704. DOI: $10.1577 / 1548-8675(1995) 015<0688$ : GNMAPR $>2.3 . \mathrm{CO} ; 2$

Bhagat Y., Fox M.G., Ferreira M.T. 2006. Morphological differentiation in introduced pumpkinseed Lepomis gibbosus (L.) occupying different habitat zones in Portuguese reservoirs. Journal of Fish Biology 69 (Suppl. sc): 79-94. DOI: 10.1111/j.1095-8649.2006.01267.x

Blackwell B.G., Brown M.L, Willis D.W. 2000. Relative weight $(W r)$ status and current use in fisheries assessment and management. Reviews in Fisheries Science 8 (1): 1-44. DOI: 10.1080/10641260091129161

Bonar S.A., Bolding B.D., Divens M., Meyer W. 2005. Effects of introduced fishes on wild juvenile coho salmon in three shallow Pacific Northwest lakes. Transactions of the American Fisheries Society 134 (3): 641-652. DOI: 10.1577/T04-154.1

Braband A., Saltveit S.J. 1989. Ecological aspects of the fish fauna in three Portuguese reservoirs. Archiv für Hydrobiologie 114 (4): 575-589.

Brown T.G., Runciman B., Pollard S., Grant A.D.A. 2009. Biological synopsis of largemouth bass (Micropterus salmoides). Canadian Manuscript Report of Fisheries and Aquatic Sciences No. 2884.

Chesson J. 1978. Measuring preference in selective predation. Ecology 59 (2): 211-215. DOI: 10.2307/1936364

Chesson J. 1983. The estimation and analysis of preference and its relationship to foraging models. Ecology 64 (5): 1297-1304. DOI: $10.2307 / 1937838$
Clavero M., Hermoso V., Aparicio E., Godinho F.N. 2013. Biodiversity in heavily modified waterbodies: native and introduced fish in Iberian reservoirs. Freshwater Biology 58 (6): 1190-1201. DOI: 10.1111/fwb.12120

Costello M.J. 1990. Predator feeding strategy and prey importance: a new graphical analysis. Journal of Fish Biology 36 (2): 261-263. DOI: 10.1111/j.1095-8649.1990.tb05601.x

Dumont S.C., Dennis J.A. 1997. Comparison of day and night electrofishing in Texas reservoirs. North American Journal of Fisheries Management 17 (4): 939-946. DOI: 10.1577/ 1548-8675(1997)017<0939:CODANE >2.3.CO;2

Fontoura A.P., De Pauw N. 1991. Macroinvertebrate community structure and impact assessment of dams and impounded rivers in the Cávado River basin (Northern Portugal). Verhandlungen des Internationalen Verein Limnologie 24: 1353-1359.

Fox M.G., Vila-Gispert A., Copp G.H. 2007. Life-history traits of introduced Iberian pumpkinseed Lepomis gibbosus relative to native populations. Can differences explain colonization success? Journal of Fish Biology 71 (Suppl. sd), 56-69. DOI: 10.1111/j.1095-8649.2007.01683.x

Gabelhouse D.W.jr. 1987. Responses of largemouth bass and bluegills to removal of surplus largemouth bass from a Kansas pond. North American Journal of Fisheries Management 7 (1): 81-90. DOI: 10.1577/1548-8659(1987) $7<81$ :ROLBAB $>2.0 . \mathrm{CO} ; 2$

García-Berthou E. 2002. Ontogenetic diet shifts and interrupted piscivory in introduced largemouth bass (Micropterus salmoides). International Review of Hydrobiology 87 (4): 353-363. DOI: 10.1002/1522-2632(200207)87:4<353:: AID-IROH353>3.0.CO;2-N

García-Berthou E., Moreno-Amich R. 1993. Multivariate analysis of covariance in morphometric studies of the reproductive cycle. Canadian Journal of Fisheries and Aquatic Sciences 50 (7): 1394-1399. DOI: 10.1139/f93-159

García-Berthou E., Moreno-Amich R. 2000a. Food of introduced pumpkinseed sunfish: ontogenetic diet shift and seasonal variation. Journal of Fish Biology 57 (1): 29-40. DOI: 10.1111/j.1095-8649.2000.tb00773.x

García-Berthou E., Moreno-Amich R. 2000b. Introduction of exotic fish into a Mediterranean lake over a 90 -year period. Archiv für Hydrobiologie 149 (2): 271-284.

Godinho F.N., Ferreira, M.T. 2006. Influence of habitat structure on the fish prey consumption by largemouth bass, Micropterus salmoides, in experimental tanks. Limnetica 25 (3): 657-664.

Godinho F.N., Ferreira M.T., Cortes R.V. 1997. The environmental basis of diet variation in pumpkinseed sunfish, Lepomis gibbosus, and largemouth bass, Micropterus salmoides, along an Iberian river basin. Environmental Biology of Fishes 50 (1): 105-115. DOI: 10.1023/ A:1007302718072

Gotelli N.J., Graves G.R. 1996. Null models in ecology. Smithsonian Institution Press, Washington, DC, USA.

Hardin S., Connor L.L. 1992. Variability of electrofishing crew efficiency, and sampling requirements for estimating reliable catch rates. North American Journal of Fisheries Management 12 (3): 612-617. DOI: 10.1577/1548-8675 (1992)012<0612:VOECEA $>2.3 . C O ; 2$ 
He X., Hodgson J.R., Kitchell J.F., Wright R.A. 1994. Growth and diet composition of largemouth bass (Micropterus salmoides) from four experimental lakes. Verhandlungen des Internationalen Verein Limnologie 25 (4): 2092-2097.

Hermoso V., Clavero M., Blanco-Garrido F., Prenda J. 2011. Invasive species and habitat degradation in Iberian streams: an analysis of their role in freshwater fish diversity loss Ecological Applications 21 (1): 175-188. DOI: 10.1890/09-2011.1

Hodgson J.R., Hodgson C.J., Brooks S.M. 1991. Trophic interaction and competition between largemouth bass (Micropterus salmoides) and rainbow trout (Oncorhynchus mykiss) in a manipulate lake. Canadian Journal of Fisheries and Aquatic Sciences 48 (9): 1704-1712. DOI: 10.1139/f91-202

Hoyle J.A., Keast A. 1987. The effect of prey morphology and size on handling time in a piscivore, the largemouth bass (Micropterus salmoides). Canadian Journal of Zoology 65 (8): 1972-1977. DOI: 10.1139/z87-300

Keast A. 1978. Feeding interrelations between age-groups of pumpkinseed (Lepomis gibbosus) and comparisons with bluegill (L. macrochirus). Journal of the Fisheries Research Board of Canada 35 (1): 12-27. DOI: 10.1139/f78-003

Liao H., Pierce C.L., Wahl D.H., Rasmussen J.B., Leggett W.C. 1995. Relative weight $\left(W_{r}\right)$ as a field assessment tool: Relationships with growth, prey biomass, and environmental conditions. Transactions of the American Fisheries Society 124 (3): 387-400. DOI: 10.1577/1548-8659 (1995)124<0387:RWWRAA>2.3.CO;2

Marshall S., Elliott M. 1997. A comparison of univariate and multivariate numerical and graphical techniques for determining inter- and intraspecific feeding relationships in estuarine fish. Journal of Fish Biology 51 (3): 526-545. DOI: 10.1111/j.1095-8649.1997.tb01510.x

Mittelbach G.G. 1984. Predation and resource partitioning in two sunfishes (Centrarchidae). Ecology 65 (2): 499-513. DOI: $10.2307 / 1941412$

Mittelbach G.G., Osenberg C., Wainwright P.C. 1992. Variation in resource abundance affects diet and feeding morphology in the pumpkinseed sunfish (Lepomis gibbosus). Oecologia 90 (1): 8-13. DOI: 10.1007/BF00317802

Oliveira J.M., Ferreira M.T., Morgado P., Hughes R.M., Teixeira A., Cortes R.M., Bochechas J. 2009. A preliminary fishery quality index for Portuguese streams. North American Journal of Fisheries Management 29 (5): 1466-1478. DOI: 10.1577/M08-175.1

Olson M.H., Mittelbach G.G., Osenberg C.W. 1995. Competition between predator and prey: resource-based mechanisms and implications for stage-structured dynamics. Ecology 76 (6): 1758-1771. DOI: 10.2307/1940708

Osenberg C.W., Mittelbach G.G., Wainwright P.C. 1992. Two-stage life histories in fish: the interaction between juvenile competition and adult performance. Ecology 73 (1): 255-267. DOI: 10.2307/1938737

Osenberg C.W., Werner E.E., Mittelbach G.G., Hall D.J. 1988. Growth patterns in bluegill (Lepomis macrochirus) and pumpkinseed (L. gibbosus) sunfish: environmental variation and the importance of ontogenetic niche shifts. Canadian Journal of Fisheries and Aquatic Sciences 45 (1): 17-26. DOI: $10.1139 / \mathrm{f} 88-003$

Pianka E.P. 1974. Niche overlap and diffuse competition. Proceedings of the National Academy of Sciences of the USA 71 (5): 2141-2145.

Rezsu E., Specziár A. 2006. Ontogenetic diet profiles and sizedependent diet partitioning of ruffe Gymnocephalus cernuus, perch Perca fluviatilis and pumpkinseed Lepomis gibbosus in Lake Balaton. Ecology of Freshwater Fish 15 (3): 339-349. DOI: 10.1111/j.1600-0633.2006.00172.x

Robinson B.W., Wilson D.S., Margosian A.S. 2000. A pluralistic analysis of character release in pumpkinseed sunfish (Lepomis gibbosus). Ecology 81 (10): 2799-2812. DOI: 10.1890/0012-9658(2000)081[2799:APAOCR]2.0.CO;2

Robinson B.W., Wilson D.S., Margosian A.S., Lotito P.T. 1993. Ecological and morphological differentiation of pumpkinseed sunfish in lakes without bluegill sunfish. Evolutionary Ecology 7 (5): 451-464. DOI: 10.1007/ BF01237641

Shoup D.E., Callahan S.P., Wahl D.H., Pierce C.L. 2007. Size-specific growth of bluegill, largemouth bass and channel catfish in relation to prey availability and limnological variables. Journal of Fish Biology 70 (1): 21-34. DOI: 10.1111/j.1095-8649.2006.01204.x

Vila-Gispert A., Fox M.G., Zamora L., Moreno-Amich R. 2007. Morphological variation in pumpkinseed Lepomis gibbosus introduced into Iberian lakes and reservoirs; adaptations to habitat type and diet? Journal of Fish Biology 71 (1): 163-181. DOI: 10.1111/j.1095-8649.2007. 01483.x

Wahl D.H., Stein R.A., DeVries D.R. 1995. An ecological framework for evaluating the success and effects of stocked fishes. Pp. 176-189. In: Schramm H.L., Piper R.G. (eds.) Uses and effects of cultured fish in aquatic ecosystems. American Fisheries Society Symposium No. 15.

Werner E.E. 1974. The fish size, prey size, handling time relation in several sunfishes and some implications. Journal of the Fisheries Research Board of Canada 31 (9): 1531-1536. DOI: $10.1139 / \mathrm{f} 74-186$

Wetzel R.G. 1990. Reservoir ecosystems, conclusions and speculations. Pp. 227-238. In: Thornton K.W., Kimmel B.L., Paine F.E. (eds.) Reservoir limnology: ecological perspectives. John Wiley and Sons, Somerset, NJ, USA.

Zapata S.C., Granado-Lorencio C. 1993. Age, growth and feeding of the exotic species Lepomis gibbosus in a Spanish cooling reservoir. Archiv für Hydrobiologie 90 (Suppl.): 561-573.

Received: 26 February 2013

Accepted: 15 January 2014

Published electronically: 31 March 2014 